Smahel, D., Dedkova, L., Daneback, K., Walrave, M., \& Schouten, A. (2017). Editorial: A breakthrough year for Cyberpsychology: More citations, more submissions - and more impact. Cyberpsychology: Journal of Psychosocial Research on Cyberspace, 12(4). https://dx.doi.org/10.5817/CP2019-1-xx

\title{
A breakthrough year for Cyberpsychology: More citations, more submissions - and more impact
}

\author{
Editorial \\ David Smahel' ${ }^{1}$, Lenka Dedkova ${ }^{1}$, Kristian Daneback², Michel Walrave ${ }^{3}$, \& Alexander Schouten ${ }^{4}$ \\ 1 Faculty of Social Studies, Masaryk University, Brno, Czech Republic \\ 2 Faculty of Social Sciences, University of Gothenburg, Gothenburg, Sweden \\ ${ }^{3}$ Department of Communication Studies, University of Antwerp, Antwerp, Belgium \\ ${ }^{4}$ Department of Communication and Cognition, Tilburg University, Tilburg, Netherlands
}

Dear researchers, colleagues, and readers interested in internet-related research,

We are happy to present the first 2019 issue of Cyberpsychology. You might notice that the issue has been published much earlier than the first regular issues of previous years. This is one of the changes that the journal has implemented. In this editorial, we will take the opportunity to inform you about our recent progress and the other changes we have already made.

The year 2018 was a milestone for our journal. After two years of evaluations, Cyberpsychology received its first impact factor by Web of Science. In our category, multidisciplinary psychology, Cyberpsychology is in the second quartile with an impact factor of 1.400. This great evaluation is also apparent by the scores in Scopus, where Cyberpsychology reached the first quartile in categories Communication and Social science (misc.), and the second quartile in Psychology (misc.), with a SCImago Journal Rank (SJR) of 0.774. Cyberpsychology has been in Scopus since 2011 and we can observe the trend in SJR and cite the scores across years, clearly showing steady increases in the journal's recognition and impact - see Figure 1.

The increasing recognition of our journal is also reflected in the number of submissions, which more than doubled in 2018 when compared to the previous year. In 2018, authors submitted 194 new manuscripts. This has increased the pressure on our journal's editorial team to provide timely decisions. The manuscripts that were desk rejected after an internal evaluation without being sent to external reviewers (63\% of submissions), took an average of 15 days with a median of 11 days. For the submissions that went to external reviewers, the average time to receive a decision was 136 days, with a median of 121 days. This is quite similar to last year's decision times, showing that the editorial team was able to handle the new submissions well.

To accommodate the increased number of submissions, we expanded our editorial team. We were happy to welcome Michel Walrave from the University of Antwerp as a new associate editor in February 2018 and Alexander Schouten from Tilburg University came on as another associate editor in January 2019. The editorial team is now more diversified and spread across more universities and countries. 


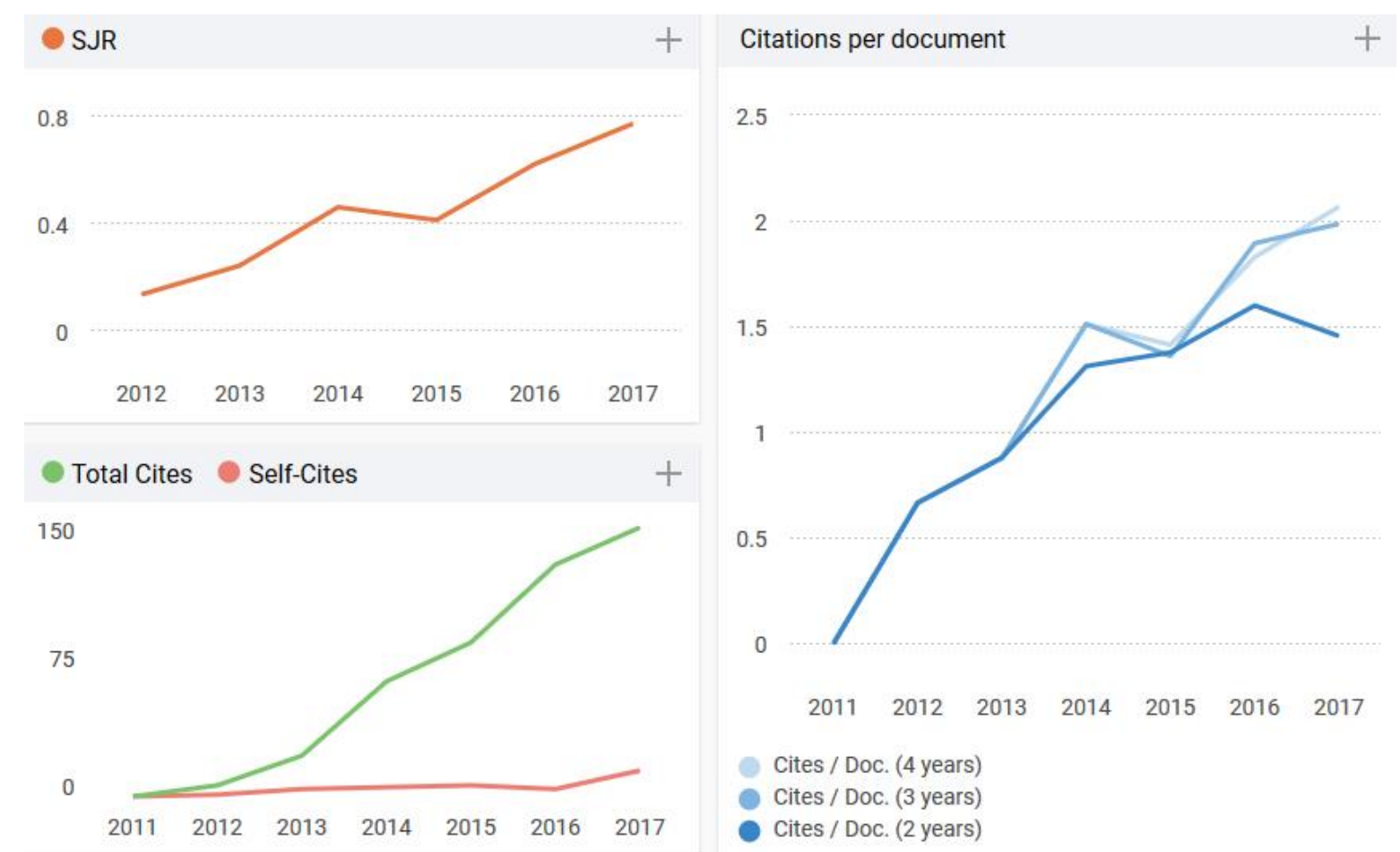

Figure 1. SCImago Journal Rank, citations per document, and total cites for Cyberpsychology from 2011 to 2017.

Source: http://www.scimagojr.com

Another addition to the journal is the new online submission system, which replaced the email submissions in January 2019. Cyberpsychology uses Open Journal Systems, which, similar to other submission systems, allows both authors and editors to keep up-to-date overviews of their submissions and their progress. Still, we are open to answer any question about author submissions at info@cyberpsychology.eu .

We can say that the year 2018 was also successful from the perspective of the amount of visitors and readers of the journal. Across the whole year, Cyberpsychology had 166,440 visits and 271,629 page views, an average of almost 14,000 visits per month. We got visitors from 203 countries. Most of the visitors came from the United States, a bit more than $15 \%$ of the visits (see Figure $2 a$ ). Figure $2 b$ shows the visits summarized by continent. It is clear that our journal attracts a global audience.

\section{2a: Ten countries with the most visits}

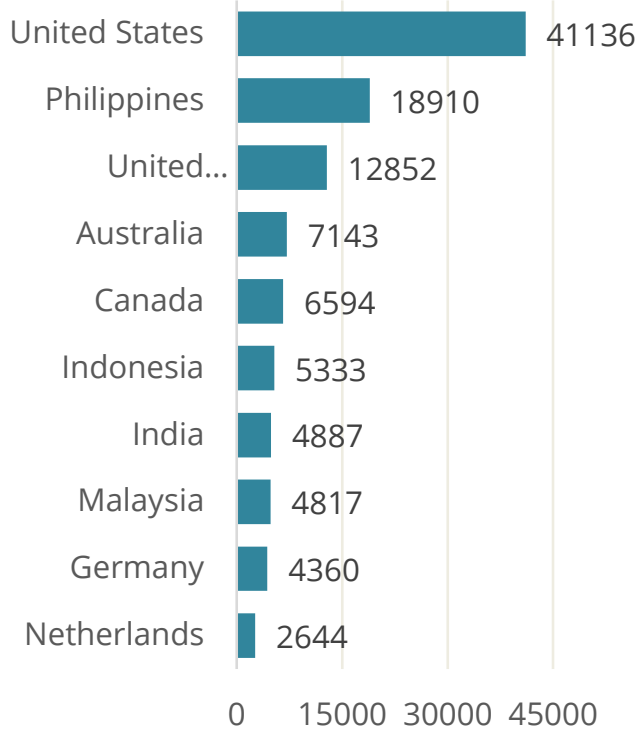

\section{2b: Visits by continent}

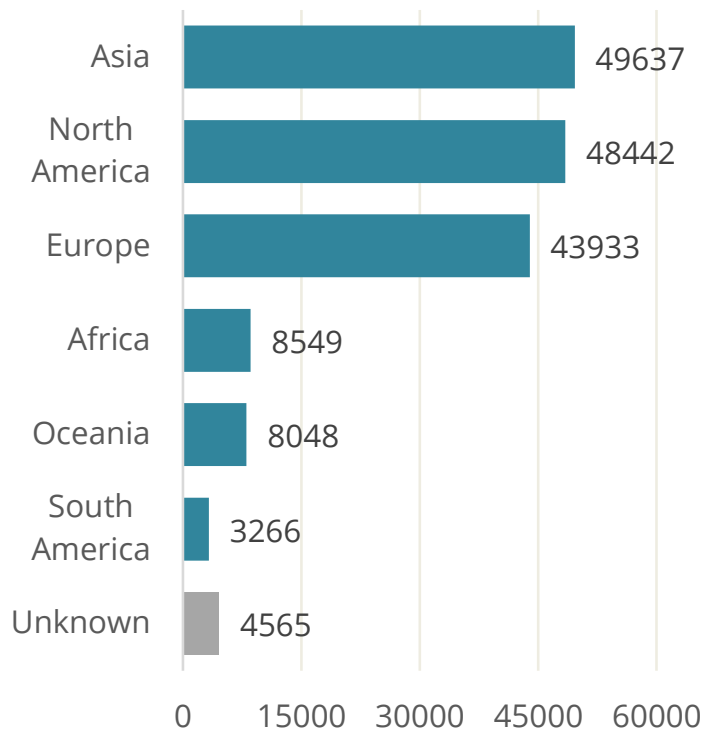

Figure 2. Location of Cyberpsychology readers in 2018. 
It is also interesting to see which articles had highest amounts of pageviews. In 2018, the winner was "The Impact of E-mail Communication on Organizational Life" by Daantje Derks and Arnold Bakker (2010) with more than 10,000 views. The Top 10 viewed articles are in Table 1 . We examine the pageviews of our articles every month and the pattern of our audience was stable throughout the whole year - the same articles scored among the Top 10 repeatedly, with only a few articles that spike for a month. The articles are from many areas, including online gaming, cyberbullying, social networking, visual impression management, and online communication. There is no clear pattern for the kinds of articles that become popular. It is worth noting that the most viewed article still attracts "only" four percent of the traffic of the whole journal, showing that the audience interests are spread across the whole site.

Table 1. Ten Most Viewed Articles in 2018.

\begin{tabular}{|c|c|c|c|c|}
\hline Authors & Article title & $\begin{array}{l}\text { Publication } \\
\text { year }\end{array}$ & Views & $\begin{array}{l}\% \text { of total } \\
\text { website } \\
\text { pageviews }\end{array}$ \\
\hline Derks, D., \& Bakker, A. B. & $\begin{array}{l}\text { The impact of e-mail communication on organizational } \\
\text { life }\end{array}$ & 2010 & 10309 & 3.80 \\
\hline $\begin{array}{l}\text { Luthman, S., Bliesener, T., \& } \\
\text { Staude-Müller, F. }\end{array}$ & $\begin{array}{l}\text { The effect of computer gaming on subsequent time } \\
\text { perception }\end{array}$ & 2009 & 7949 & 2.93 \\
\hline Šléglová, V., \& Cerna, A. & $\begin{array}{l}\text { Cyberbullying in adolescent victims: perception and } \\
\text { coping }\end{array}$ & 2011 & 4790 & 1.76 \\
\hline $\begin{array}{l}\text { Sherman, L. E., Michikyan, } \\
\text { M., \& Greenfield, P. M. }\end{array}$ & $\begin{array}{l}\text { The effects of text, audio, video, and in-person } \\
\text { communication on bonding between friends }\end{array}$ & 2013 & 4277 & 1.57 \\
\hline $\begin{array}{l}\text { Calancie, O., Ewing, L., } \\
\text { Narducci, L. D., Horgan, S., } \\
\text { \& Khalid-Khan, S. }\end{array}$ & $\begin{array}{l}\text { Exploring how social networking sites impact youth } \\
\text { with anxiety: A qualitative study of Facebook stressors } \\
\text { among adolescents with an anxiety disorder diagnosis }\end{array}$ & 2017 & 3871 & 1.43 \\
\hline $\begin{array}{l}\text { Machackova, H., Cerna, A., } \\
\text { Sevcikova, A., Dedkova, L., \& } \\
\text { Daneback, K. }\end{array}$ & $\begin{array}{l}\text { Effectiveness of coping strategies for victims of } \\
\text { cyberbullying }\end{array}$ & 2013 & 3806 & 1.40 \\
\hline Blumer, T., \& Döring, N. & $\begin{array}{l}\text { Are we the same online? The expression of the five } \\
\text { factor personality traits on the computer and the } \\
\text { Internet }\end{array}$ & 2012 & 3650 & 1.34 \\
\hline Siibak, A. & $\begin{array}{l}\text { Constructing the self through the photo selection - } \\
\text { visual impression management on social networking } \\
\text { websites }\end{array}$ & 2009 & 3325 & 1.22 \\
\hline $\begin{array}{l}\text { Lorentz, P., Ferguson, C. J., } \\
\text { \& Schott, G. }\end{array}$ & Editorial: The experience and benefits of game playing & 2015 & 3105 & 1.14 \\
\hline Utz, S., \& Krämer, N. C. & $\begin{array}{l}\text { The privacy paradox on social network sites revisited: } \\
\text { The role of individual characteristics and group norms }\end{array}$ & 2009 & 3122 & 1.15 \\
\hline
\end{tabular}

The intriguing question for us was whether the pattern in visits reflected the pattern in article citations. Thus, we took a look at the citation record in the Scopus database, which covers Cyberpsychology from the year 2011. The 10 most cited articles in 2018 are presented in Table 2. (The final number of citations will likely change when Scopus finalizes the records for 2018.) The most cited article was "Consensual sexting among adolescents: Risk prevention through abstinence education or safer sexting?" by Nicola Döring from 2014, which received 21 citations in Scopus in 2018. This is also the article which is most cited overall from all of the Cyberpsychology articles in Scopus. Interestingly, there is little overlap between Tables 1 and 2 - only one article is on both the Top 10 most visited and Top 10 most cited lists: "Effectiveness of coping strategies for victims of cyberbullying" by Hana Machackova, Alena Cerna, Anna Sevcikova, Lenka Dedkova, and Kristian Daneback. It is only good fortune that this article is co-authored by two of the editors of our journal 


\begin{tabular}{|c|c|c|c|}
\hline Authors & Article title & $\begin{array}{c}\text { Publication } \\
\text { year }\end{array}$ & $\begin{array}{c}\text { Citations in } \\
\text { Scopus in } 2018\end{array}$ \\
\hline Doring $\mathrm{N}$. & $\begin{array}{l}\text { Consensual sexting among adolescents: Risk prevention } \\
\text { through abstinence education or safer sexting? }\end{array}$ & 2014 & 21 \\
\hline Tiidenberg K. & $\begin{array}{l}\text { Bringing sexy back: Reclaiming the body aesthetic via self- } \\
\text { shooting }\end{array}$ & 2014 & 15 \\
\hline Gorzig A., Frumkin L.A. & $\begin{array}{l}\text { Cyberbullying experiences on-the-go: When social media can } \\
\text { become distressing }\end{array}$ & 2013 & 10 \\
\hline Dworkin J., Connell J., Doty J. & A literature review of parents' online behavior & 2013 & 10 \\
\hline $\begin{array}{l}\text { Walrave M., } \\
\text { Vanwesenbeeck I., Heirman } \\
\text { W. }\end{array}$ & $\begin{array}{l}\text { Connecting and protecting? Comparing predictors of self- } \\
\text { disclosure and privacy settings use between adolescents and } \\
\text { adults }\end{array}$ & 2012 & 9 \\
\hline $\begin{array}{l}\text { Sherman L.E., Michikyan M., } \\
\text { Greenfield P.M. }\end{array}$ & $\begin{array}{l}\text { The effects of text, audio, video, and in-person communication } \\
\text { on bonding between friends }\end{array}$ & 2013 & 9 \\
\hline $\begin{array}{l}\text { Machackova H., Cerna A., } \\
\text { Sevcikova A., Dedkova L., } \\
\text { Daneback K. }\end{array}$ & Effectiveness of coping strategies for victims of cyberbullying & 2013 & 9 \\
\hline $\begin{array}{l}\text { Kezer M., Sevi B., Cemalcilar } \\
\text { Z., Baruh L. }\end{array}$ & $\begin{array}{l}\text { Age differences in privacy attitudes, literacy and privacy } \\
\text { management on Facebook }\end{array}$ & 2016 & 9 \\
\hline $\begin{array}{l}\text { Pettijohn II T.F., LaPiene } \\
\text { K.E., Pettijohn T.F., Horting } \\
\text { A.L. }\end{array}$ & $\begin{array}{l}\text { Relationships between facebook intensity, friendship } \\
\text { contingent self-esteem, and personality in U.S. college students }\end{array}$ & 2012 & 8 \\
\hline $\begin{array}{l}\text { Antheunis M.L., Valkenburg } \\
\text { P.M., Peter J. }\end{array}$ & $\begin{array}{l}\text { The quality of online, offline, and mixed-mode friendships } \\
\text { among users of a social networking site }\end{array}$ & 2012 & 8 \\
\hline
\end{tabular}

\section{Articles in This Issue}

Finally, we will briefly introduce the four articles included in this issue. All of them are related in some way to the theme of social networking and all provide different insights into this still-timely part of people's lives.

The first article, "Do men post and women view? The role of gender, personality, and emotions in online social activity", aimed to examine the role of gender, personality traits, and emotional competence on each of these two belongingness-related behaviors. The authors revealed that the most relevant online behavior appears to be emotional competences, because managing emotions reduces both posting and viewing, using emotions fosters communication, and understanding emotions decreases information-seeking. According to the authors, extraversion plays a key role as well, promoting both behaviors in women and information-seeking in men, whereas openness to experiences is positively linked to viewing others' profiles.

The second article, "Social comparison orientation mediates the relationship between neuroticism and passive Facebook use", investigates the relationship between passive Facebook use, neuroticism, and social-comparison orientation among Estonian Facebook users. The authors revealed positive bivariate-correlations between passive Facebook use, neuroticism, and social comparison orientation. Furthermore, social-comparison orientation mediated the relationship between neuroticism and passive Facebook use.

The third article, "Predicting SNS addiction with the Big Five and the Dark Triad", focuses on the predictions of social networking site addiction with the Dark Triad traits (a psychological measure of personality) that have been linked to impulsivity. The researchers demonstrated that SNS addiction was associated with the measured psychopathy of the Dark Triad. 
The fourth article, "Social media addiction: Its impact, mediation, and intervention", examined the relations of social media addiction to college students' mental health and academic performance, and investigated the role of self-esteem as a mediator for the relationship. The authors revealed that social media addiction was negatively associated with the students' mental health and academic performance. In the second study focus, the researchers tested the effectiveness of intervention in reducing social media addiction. They developed and tested a two-stage intervention program. They found that their intervention was effective in reducing the students' social media addiction and improving their mental health and academic efficiency.

We hope you will find this issue interesting. We thank all of the authors, reviewers, and other people who worked on this issue and the journal. We wish you a successful 2019 and we hope you will keep reading Cyberpsychology. We can promise that our work on the improvements of the journal will continue in 2019 as well.

\title{
Issue Content
}

\section{Editorial}

\author{
Editorial: A breakthrough year for Cyberpsychology: More citations, more submissions - and more \\ impact \\ David Smahel, Lenka Dedkova, Kristian Daneback, Michel Walrave, and Alexander Schouten \\ https://dx.doi.org/10.5817/CP2019-1-xx
}

\section{Articles}

Article 1:

Do men post and women view? The role of gender, personality and emotions in online social activity Chiara Rollero, Adriano Daniele, and Stefano Tartaglia

http://dx.doi.org/10.5817/CP2019-1-1

Article 2:

Social comparison orientation mediates the relationship between neuroticism and passive Facebook use Dmitri Rozgonjuk, Tracii Ryan, Joosep Kristjan Kuljus, Karin Täht, and Graham G. Scott

https://doi.org/10.5817/CP2019-1-2

Article 3:

Predicting SNS addiction with the Big Five and the Dark Triad

Soon-Li Lee

https://dx.doi.org/10.5817/CP2019-1-3

Article 4:

Social media addiction: Its impact, mediation, and intervention

Yubo Hou, Dan Xiong, Tonglin Jiang, Lily Song, \& Qi Wang

https://doi.org/10.5817/CP2019-1-4

\section{About the Journal}

The Cyberpsychology: Journal of Psychosocial Research on Cyberspace is a web-based, peer-reviewed scholarly journal. The first peer-reviewed issue was published in September 2007. The journal is focused on social science research about cyberspace. It brings psychosocial reflections of the impact of the Internet on people and society. The journal is interdisciplinary, publishing works written by scholars of psychology, media studies, communication science, sociology, political science, nursing, ICT security, organizational psychology and also other disciplines with relevance to psychosocial aspects of cyberspace. The journal accepts original research articles, as well as theoretical studies and research meta-analyses. Proposals for special issues are also welcomed. 
The journal is indexed with Web of Science (Social Science Citation Index and Current Contents - Social \& Behavioral Sciences), SCOPUS, ERIH PLUS, EBSCO Academic Search Complete, the Directory of Open Access Journals and the Czech Database of Scientific Journals.

The articles in Cyberpsychology: Journal of Psychosocial Research on Cyberspace are open access articles licensed under the terms of the Creative Commons Attribution Non-Commercial License which permits unrestricted, noncommercial use, distribution and reproduction in any medium, provided the work is properly cited.

\section{Publication Ethics and Publication Malpractice Statement}

Cyberpsychology: Journal of Psychosocial Research on Cyberspace follows the standard for Ethics and Publication Malpractice set by the Committee on Publication Ethics (COPE). Authors, reviewers, editors, and publisher are expected to conform to these standards.

\section{Editor}

Prof. David Smahel, M.Sc. et Ph.D., Faculty of Social Studies, Masaryk University, Czech Republic

E-mail: smahel(at)fss.muni.cz

\section{Associate Editors}

Prof. Kristian Daneback, Ph.D., University of Gothenburg, Sweden

E-mail: kristian.daneback(at)socwork.gu.se

Prof. Michel Walrave, Ph.D., University of Antwerp, Belgium

E-mail: michel.walrave(at)uantwerpen.be

Assist. Prof. Alexander Schouten, Ph.D., Tilburg University, Netherlands

E-mail: a.p.schouten(at)tilburguniversity.edu

Lenka Dedkova, Ph.D., Masaryk University, Czech Republic

E-mail: Idedkova(at)fss.muni.cz

\section{Managing Editor}

Lenka Dedkova, Ph.D., Faculty of Social Studies, Masaryk University, Czech Republic

E-mail: Idedkova(at)fss.muni.cz

\section{Editorial Assistant}

Marie Bedrošová, M.A. \& M.A., Masaryk University, Czech Republic

E-mail: marie.bedrosova(at)mail.muni.cz

\section{Editorial Board}

Prof. Jochen Peter, Ph.D., University of Amsterdam, Netherlands

Prof. Veronika Kalmus, Ph.D., University of Tartu, Estonia

Prof. Gustavo S. Mesch, Ph.D., University of Haifa, Israel

Prof. Kaveri Subrahmanyam, Ph.D., California State University, Los Angeles, USA

Prof. Herbert Hrachovec, Ph.D., University of Vienna, Austria

Prof. Dr. Micheline Frenette, Universite de Montreal, Canada

Prof. Alexander E. Voiskounsky, Ph.D., Lomonosov Moscow State University, Russia

Prof. Michael W. Ross, Ph.D., DrMedSc, MPH, MPHEd, University of Texas, Houston, USA 
Prof. Olle Findahl, World Internet Institute, Sweden

Prof. Joshua Fogel, Ph.D., Brooklyn College of the City University of New York, USA

Prof. Lelia Green, Ph.D., Edith Cowan University, Australia

Prof. Andra Siibak, Ph.D., University of Tartu, Estonia

Hana Machackova, Ph.D., Masaryk University, Czech Republic

Michelle Wright, Ph.D., Pennsylvania State University, USA

Václav Štětka, Ph.D., Loughborough University, United Kingdom

Adjunct Prof. Birgit U. Stetina, Ph.D., University of Vienna, Austria

Anna Sevcikova, Ph.D., Masaryk University, Czech Republic

\section{Advisory Board}

Prof. Bente Traen, Ph.D., University of Oslo, Norway

Prof. Charles Ess, Ph.D., University of Oslo, Norway

Prof. Dr. Ilse Kryspin-Exner, University of Vienna, Austria

Prof. PhDr. Jan Jirák, Ph.D., Charles University, Czech Republic

Prof. Vasja Vehovar, Ph.D., University of Ljubljana, Slovenia

Prof. Larry D. Rosen, Ph.D., California State University, USA

Prof. Patricia M. Greenfield, Ph.D., University of California, USA

Prof. Peter K Smith, University of London, England

Prof. Petr Macek, CSc., Masaryk University, Czech Republic

Prof. Nicola Döring, Ilmenau University of Technology, Germany

Prof. Kimberly Young, Ph.D., St. Bonaventure University, USA

Prof. Jos de Haan, Ph.D., Erasmus University, Netherlands

Prof. Monica Whitty, Ph.D., The University of Melbourne, Australia \& The University of Warwick, UK

Prof. Alistair Duff, Ph.D., Edinburgh Napier University, Scotland

Assoc. Prof. Alfred Choi, Ph.D., Nanyang Technological University, Singapore

Prof. Thurasamy Ramayah, Universiti Sains Malaysia, Malaysia

Assoc. Prof. Neil Coulson, Ph.D., The University of Nottingham, UK

Assoc. Prof. Kenneth C. C. Yang, Ph.D., University of Texas at El Paso, USA

Assoc. Prof. Sun Sun Lim, Ph.D., National University of Singapore, Singapore

Prof. Sameer Hinduja, Ph.D., Florida Atlantic University, USA

Assoc. Prof. Jana Horáková, Ph.D., Masaryk University, Czech Republic

Assoc. Prof. Radim Polčák, Ph.D., Masaryk University, Czech Republic

Assoc. Prof. Pille Pruulmann-Vengerfeldt, Ph.D., University of Tartu, Estonia

Assist. Prof. Alexander Schouten, Ph.D., Tilburg University, Netherlands

Assist. Prof. Ewa S. Callahan, Ph.D., Quinnipiac University, USA

Assist. Prof. Regina van den Eijnden, Ph.D., Utrecht University, Netherlands

Assist. Prof. Veysel Demirer, Ph.D., Süleyman Demirel Üniversitesi, Turkey

PhDr. Ing. Petr Soukup, Charles University, Czech Republic

Janis Wolak, Ph.D., University of New Hampshire, USA

Francesca Romana Seganti, Ph.D., Sapienza University of Rome, Italy

Jeff Gavin, Ph.D., University of Bath, UK

Michael Fenichel, Ph.D., New York, USA

Leslie Haddon, Ph.D., London School of Economics, UK

Fabio Sticca, Ph.D., Marie Meierhofer Institut für das Kind, Zürich, Switzerland

\section{Publisher}

Masaryk University, Faculty of Social Studies

Jostova 10, 60200 Brno

Czech Republic 